\title{
Двадцятирічний досвід операції легеневого аутографта
}

\author{
Романюк О. М. ${ }^{1,2}$, Климишин Ю. І. ${ }^{1}$, Руденко Н. М. ${ }^{1,2}$, Довгань О. М. ${ }^{1}$ Ємець І. М. ${ }^{1,2}$ \\ ${ }^{1}$ ДУ «Науково-практичний медичний центр дитячої кардіології та кардіохірургії МОЗ України» (Київ) \\ ${ }^{2}$ Національна медична академія післядипломної освіти імені П. Л. Шупика (Київ)
}

\begin{abstract}
В роботі проаналізовано результати операції заміни аортального клапана власним клапаном легеневої артерії (операція легеневого аутографта) у пацієнтів з аортальними вадами, представлено власні модифікації хірургічних технік.
\end{abstract}

Мета роботи - проаналізувати двадцятирічний досвід операції легеневого аутографта, визначити причини дисфункції аутографта у віддаленому періоді, оцінити вплив методики укріплення кореня аорти на результати операції.

Матеріал дослідження становили 200 послідовних пацієнтів різних вікових груп, яким виконана операція легеневого аутографта за період з 1996 по 2017 р. У 127 пацієнтів використовували власні хірургічні модифікації з укріплення кореня аутографта і формування нової легеневої артерії.

Результати. За період спостереження виживаність склала 95,3\%, 92,1\% і 92,1\% через 1, 10 та 15 років відповідно. Виявлено такі фактори ризику летальності: вік пацієнтів до 1 року, збільшення часу перетискання аорти та штучного кровообігу. Ризик достовірно зменшувався при використанні власних хірургічних модифікацій. Неоаортальна недостатність (неоАІ) спостерігалась: до 1-го ступеня (мінімальна) - у 130 (76\%) пацієнтів, до 2-го ступеня (до невеликої) - у 25 (15\%), до 3-го ступеня (помірно виражена) - у 10 (6\%), вище 3-го ступеня (виражена) - у 5 (3\%). Виявлено такі предиктори збільшення ризику дисфункції аутографта: вік пацієнтів (його збільшення призводило до збільшення ризику виникнення неоАI $(\mathrm{p}=0,001)$ ), доопераційний клінічний стан (ФК за NYHA), тривалість операції ( $\mathrm{p}=0,002)$. Застосування модифікацій укріплення кореня неоаорти знижувало ризик виникнення неоАI ( $\mathrm{p}=0,002)$.

Висновки. Використання легеневого клапана як аортального протеза забезпечує ріст неоаортального кореня, низьку частоту дисфункції аортального клапана та низьку частоту повторних втручань на ньому. Розроблені модифікації операції показали свою ефективність, значно покращивши безпосередні та віддалені результати.

Ключові слова: легеневий аутографт, аортальна вада, кондуї, операція Росса.

Операція заміни аортального клапана (AV) власним легеневим клапаном-аутографтом (операція Росса), вперше описана D. Ross в 1967 році, вважається операцією вибору при лікуванні аортальних вад у дітей і підлітків [1-3]. На сьогодні ризики цієї операції можна порівняти 3 іншими методами заміни $\mathrm{AV}$, однак легеневий клапан анатомічно, гістологічно та функціонально майже ідентичний аортальному, спроможний до росту після пересадки в аортальну позицію i, головне, не потребує антикоагулянтної терапії [1-4]. Перша операція легеневого аутографта в Україні та в країнах пострадянського простору була виконана в 1996 році в Національному інституті серцево-судинної хірургії імені М. М. Амосова. На теперішній час найбільший досвід іï виконання має Науково-практичний медичний центр дитячої кардіології та кардіохірургії МО3 України. В роботі узагальнено досвід операції легеневого аутографта, представлено модифікації хірургічної техніки. На матеріалі 200 хворих 3 аортальними вадами, прооперованих за 1996-2017 рр., проаналізовано безпосередні та віддалені результати, визначено фактори ризику летальності, порушення функції аутографта та реоперацій, досліджено вплив власних технічних нововведень на безпосередні та віддалені результати операції.

Мета роботи - проаналізувати двадцятирічний досвід операції легеневого аутографта, визначити причини дисфункції аутографта у віддаленому періоді, оцінити вплив методики укріплення кореня аорти на результати операції.

Матеріали дослідження. 31996 по 2017 роки операція легеневого аутографта була проведена 200 пацієнтам. Вік пацієнтів на момент операції становив

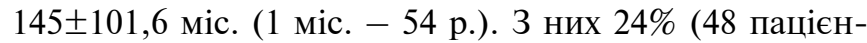
тів) були віком до 5 років, 18\% (36 хворих) - від 6 до 10 років, 30\% (59 пацієнтів) - від 11 до 15 років, 28\% (57 пацієнтів) -понад 16 років. Середня вага становила 40,2 22,7 кг (від 3 кг до 119 кг). Пацієнтів чоловічої статті було $78 \%(\mathrm{n}=156)$, жіночої - $22 \%(\mathrm{n}=44)$.

Показаннями до хірургічного втручання на аортальному клапані у переважної кількості пацієнтів був аортальний стеноз (AS) - 100 (50\%) пацієнтів, аортальна недостатність (AI) діагностована у 80 (40\%). Комбінована аортальна вада (DAL) відмічалась у 20 (10\%) хворих. За 
даними ехокардіографії у пацієнтів з AS систолічний гра-

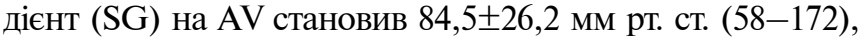
ступіньАI - у середньому 0,5+ (від 0 до 2,5+). У хворих із доопераційною AI ступінь регургітації на AV становив у середньому $3+(2,5-4), \mathrm{SG}-32,5 \pm 8,2$ мм рт. ст. (6-50). У пацієнтів із комбінованою аортальною вадою ступінь АI складав у середньому $1,5+(0,5-2,5), \mathrm{SG}-32 \pm 9,7$ мм рт. ст. (22-63). Вроджена аортальна вада була виявлена у 167 (84\%) пацієнтів, ревматична природа вади - у 18 (9\%), інфекційне ураження $\mathrm{AV}$ - у 10 (5\%), ятрогенне ураження $\mathrm{AV}$ після попередніх серцевих операцій, не пов'язаних 3 $\mathrm{AV},-$ у 5 (2\%) пацієнтів. У 148 (74\%) пацієнтів був діагностований двостулковий аортальний клапан.

Попередні оперативні втручання були проведені у $93(46,5 \%)$ пацієнтів, у них було виконано 112 операцій. У 45 (22,5\%) пацієнтів втручання виконано з використанням штучного кровообігу, у 9 (4,5\%) - без використання штучного кровообігу, балонна вальвулопластика AV проведена у 55 (27,5\%) пацієнтів.

Супутня серцева патологія була діагностована у 31 $(15,5 \%)$ хворого, в основному це була обструкція вихідного тракту лівого шлуночка ( LVOTO) $($ у $11 \%, \mathrm{n}=21)$ та патологія мітрального клапана $(4 \%, \mathrm{n}=8)$. На момент операції майже кожен шостий пацієнт $(16 \%-32$ хворих) мав важкі клінічні прояви аортальної вади і відносився до III-IV функціонального класу за NYHA, 10 з них були в критично важкому стані і потребували ШВЛ та інотропної підтримки.

Хірургічний етап. У 197 пацієнтів операція легеневого аутографта проходила за методикою «заміна кореня аорти», у 18 з них заміна аортального клапана супроводжувалася передньою аортовентрикулопластикою (процедура Ross-Konno). У 3 пацієнтів операція проводилася за методикою «субкоронарна імплантація». Хірургічні етапи операції детально описані в попередніх публікаціях $[4,5]$.

32008 р. ми доповнили хірургічний протокол операції. У 127 пацієнтів були використані розроблені нами методики укріплення кореня аутографта та формування нової легеневої артерії. Вони включали: 1) зовнішнє укріплення легеневого аутографта (некоронарного та частин коронарних синусів) залишками аортальної стінки; 2) подвійний шов проксимального та дистального анастомозів при імплантації аутографта; 3) формування задньої стінки «нової» легеневої артерії залишками аортальної стінки та повну реконструкцію легеневої артерії на перетиснутій аорти. У 73 хворих нові методики не використовувались.

Для формування нової легеневої артерії були використані: власноруч створені тристулкові PTFEкондуїти - у 54 (27\%) пацієнтів, тристулкові дакронові кондуїти - у 33 (16,5\%), ксенографти - у 32 (16\%), гомографти - у 18 (9\%), тристулкові аутоперикардіальні кондуїти - у 43 (21,5\%), відновлення легеневої артерії за допомогою залишку нативної ЛА із моностулкою - у 16 (8\%), аутоперикардіальний кондуїт із трьома стулками з мембрани Matrix - у 4 (2\%). Діаметр кондуїта в легеневій позиції варіював від 12 до 32 мм, становлячи в середньому $23,9 \pm 4,2$ мм.

Середній часперетиснення аорти склав $116,3 \pm 24,9$ хв.

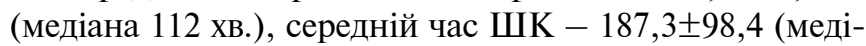

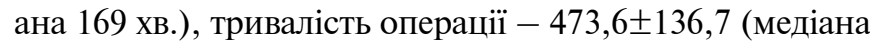
470 хв.).

Результати та обговорення. Із 200 прооперованих пацієнтів у ранньому післяопераційному періоді померло 13 (6,5\%). У віддаленому післяопераційному періоді померло 5 (2,5\%) пацієнтів. Загальна летальність склала 9\% (n=18). У віковій структурі летальності переважали діти до 1 року (померло 7 пацієнтів). Із клініки в задовільному стані виписано $187(93,5 \%)$ хворих. Віддалений період спостереження склав $96 \pm 67$ міс. (від 3 до 240 міс.). Віддалені результати простежено у 175 $(93,4 \%)$ пацієнтів. Вибуло зі спостереження 12 хворих.

Виживаність пацієнтів дослідження склала: однорічна - 95,3\% (90,1-98,7; 95\% CI), 10-річна - 92,1\% (87,4-96,1; 95\% CI), 20-річна - 92,1\% (87,3-95,8; 95\% CI). За даними бінарної логістичної регресії було створено математичну прогностичну модель виживаності. Факторами, що зменшили виживаність, були вік пацієнтів до 1 року $(\mathrm{r}=0,019, \mathrm{p}=0,012)$, збільшення тривалості ішемічного часу $(\mathrm{r}=0,031, \mathrm{p}=0,046)$ та штучного кровообігу ( $\mathrm{r}=0,007, \mathrm{p}=0,038)$. Фактором, що збільшив виживаність, стало використання власних хірургічних модифікацій операції $(\mathrm{r}=1,28 \mathrm{p}=0,048)$.

Функція неоаортального клапана. В ранньому післяопераційному періоді SG на AV становив (медіана) 7 мм рт. ст. [4; 11; 95\% CI] $(3 ; 19)$, у віддаленому періоді - 8 мм рт. ст. [5; 13; 95\% CI] $(2 ; 59)$, у $7(3,7 \%)$ пацієнтів у віддаленому періоді SG на аутографті перевищував 20 мм рт. ст., в одного з них був більший за 40 мм рт. ст. Неоаортальна недостатність (неоАI) спостерігалась: до 1-го ступеня (мінімальна) - у 130 (76\%) пацієнтів, до 2-го ступеня (до невеликої) - у 25 (15\%), до 3-го ступеня (помірно виражена) - у 10 (6\%), вище 3-го ступеня (виражена) - у 5 (3\%). Прогностична модель розвитку неоАІ виявила такі предиктори збільшення ризику дисфункції аутографта: вік пацієнтів (його збільшення призводило до збільшення ризику виникнення неоАI; $p=0,001$ ); доопераційний клінічний стан (ФК за NYHA): важчий д/о стан (NYHA III-IV) збільшував ризик появи неоАI $(\mathrm{p}=0,01)$; тривалість операції $(\mathrm{p}=0,002)$. Натомість застосування модифікацій укріплення кореня неоаорти знижувало ризик виникнення неоАI $(\mathrm{p}=0,002)$.

У віддаленому періоді z-score сегментів кореня аутографта складав: базального кільця аутографта - у середньому $3,2 \pm 1,3(0,3 ; 5,4)$, синусів Вальсальви $4,2 \pm 1,7(0,5 ; 8,8)$, синотубулярного з'єднання $-4,6 \pm 2,2$ $(0,8 ; 10,6)$. Дилатація неоаортального кореня (z-score $>2$ більш ніж двох сегментів) у віддаленому періоді спостерігалась у 87 (46,3\%) пацієнтів. 
Повторні втручання. У 10 пацієнтів на аутографті у віддаленому періоді після операції Росса (OP) проведено 11 (6,5\%) реоперацій. Показаннями до повторних оперативних втручань за даними ЕхоКГ була виражена неоаортальна недостатність із дилатацією кореня та висхідної аорти, в одного пацієнта - виражений субаортальний стеноз. Середній період після ОР до повторного оперативного втручання на аутографті склав 154,3 міс. (від 12 до 212 міс.). Структура повторних оперативних втручань на аутографті після ОР представлена: процедурою Бентала $(\mathrm{n}=5$, $2,9 \%)$, протезуванням АK $(\mathrm{n}=1,0,6 \%)$, процедурою Девіда $(\mathrm{n}=1,0,6 \%)$, пластикою $\mathrm{AK}(\mathrm{n}=2,1,2 \%)$; одному з пацієнтів була проведена пластика АK та усунення субаортального стенозу; операцією Якуба $(\mathrm{n}=1,0,6 \%)$. У пацієнта $(0,6 \%)$ після операції Якуба спостерігалася виражена недостатність на аутографті, що було показанням через 24 міс. до протезування аортального клапана. Свобода від реоперацій на аутографті склала 99,4\%, 98,9\%, 95,4\%, 93,7\% через 5,10 , 15 та 20 років відповідно.

Факторами ризику виникнення реоперацій на аутографті, за даними покрокової бінарної логістичної регресії, стали збільшення віку оперованих $(\mathrm{r}=0,010$, $\mathrm{p}=0,033)$ та незастосування методики укріплення кореня аутографта $(\mathrm{r}=1,864, \mathrm{p}=0,044)$.

На кондуїті ЛА частота виконання реоперацій у віддаленому післяопераційному періоді склала 18,8\% $(\mathrm{n}=32)$. Середній період від ОР до заміни кондуїту становив 64 міс. (від 4 до 212 міс.). За даними ЕхоКГ, основною причиною повторних втручань став виражений стеноз кондуїту в 24 (14\%) пацієнтів із середнім піковим градієнтом тиску на кондуїті $66 \pm 10,3$ мм рт. ст. (від 50 до 87 мм рт. ст.). У 3 (1,8\%) пацієнтів спостерігалася виражена недостатність на кондуїті ЛА, у 5 (2,9\%) інфекційний ендокардит кондуїту ЛА. Перед заміною кондуїту/пластикою проведено 17 (10\%) балонних дилатацій стенозу кондуїту без значущого ефекту, тому в подальшому було виконане хірургічне лікування. У 15 (8,8\%) пацієнтів проведена балонна дилатація кондуїту із задовільним результатом, що на даний момент не потребує повторних втручань. Усього проведено 32 $(18,8 \%)$ ангіопроцедури пацієнтам після операції Росса. Свобода від реоперацій на ВТПШ становила 90,2\%, $84,1 \%, 83,6 \%, 82,4$ через $5,10,15$ та 20 років відповідно. Свобода від реінтервенцій на ВТПШ - 86,4\%, 83,7\%, $82,5 \%, 82,5 \%$ через 5, 10, 15 та 20 років відповідно

Клінічний стан пацієнтів після операції. До I-II функціонального класу за NYHA у віддаленому післяопераційному періоді входила переважна більшість пацієнтів - 181 (96\%). Із 7 пацієнтів, що до операції знаходились у критичному стані (IV функціональний клас), клінічний стан значно покращився у 4, 1 пацієнт продовжував знаходитися після операції у важкому клінічному стані (III функціональний клас) через важкий неврологічний дефіцит. Після виписки всім пацієнтам дослідження планово призначалася терапія інгібіторами АПФ. Жоден із пацієнтів, яким була проведена операція легеневого аутографта, не отримував антикоагулянтну терапію, при цьому не було зафіксовано жодного випадку тромбоемболічних ускладнень.

Висновки. Результати застосування операції легеневого аутографта у пацієнтів із вадами аортального клапана переконливо демонструють унікальні переваги операції легеневого аутографта над іншими методами заміни аортального клапана. Оцінюючи власний досвід, можна впевнено стверджувати, що операція легеневого аутографта при технічній складності, що визначає достатньо високий ризик післяопераційних ускладнень і летальності, супроводжувалася невисокою летальністю, задовільними безпосередніми і віддаленими результатами та задовільним клінічним станом у переважною більшості пацієнтів.

Ехокардіографічна оцінка функції легеневого аутографта та лівого шлуночка в післяопераційному періоді показала, що легеневий клапан в аортальній позиції здатний функціонувати тривалий час, показники його функції та функції лівого шлуночка були задовільними у більшості пацієнтів. Значне і достовірне зменшення систолічного градієнту після операції та відсутність обструкції вихідного тракту лівого шлуночка протягом усього періоду спостереження у пацієнтів із соматичним ростом є свідченням здатності нового кореня аорти до фізіологічного росту.

Жоден із пацієнтів, яким була виконана операція легеневого аутографта, не мав тромбоемболічних ускладнень, пов'язаних із функцією аутопротеза, не вживаючи при цьому антикоагулянтів. Відсутність антикоагулянтної терапії та відсутність тромбоемболічних ускладнень - переваги використання легеневого аутографта, що обгрунтовує можливість використання аутографта для заміни аортального клапана у жінок, які планують вагітність (антикоагулянти негативно впливають на розвиток плода, на перебіг вагітності та збільшують ризик ускладнень пологів), та у пацієнтів із протипоказаннями до прийому антикоагулянтів.

\section{Лiтература}

1. Ross D. N. Replacement of aortic and mitral valves with a pulmonary autograft / Ross D. N. // Lancet. - 1967. Vol. 2. - P. 956-958.

2. Two decades of experience with the Ross operation in neonates, infants and children from the Italian Paediatric Ross Registry / G. B. Luciani, G. Lucchese, A. Carotti et al. // Heart. - 2014. - Vol. 100. - P. 1954-1959.

3. Pulmonary Autograft - The Ross Procedure in Its Second Decade: A Single-Center Experience in 645 Patients / T. Weimar, E. Charitos, M. Liebrich et al. // Ann Thorac Surg. - 2014. - Vol. 97. - P. 167-74.

4. Романюк О. М. Вплив хірургічних модифікацій на безпосередні результати операції легеневого аутографта / 
Романюк О. М. // Вісник серцево-судинної хірургії. 2016. - Вип. 25 (2). - С. 64-66.

5. Лечение аортальных пороков сердца у пациентов детского возраста. Операция легочного аутографта / Ро- манюк А. Н., Климишин Ю. И., Артеменко Е. А. и др. // Педиатрия. Восточная Европа. - 2016. - Т. 4, № 4. - С. 538-544.

\title{
20-years experiens of pulmonary autograft operation
}

\author{
Romanyuk O. M. ${ }^{1,2}$, Klymyshyn Y. I. ${ }^{1}$, Rudenko N. N. ${ }^{1,2}$, Dovgan A. M. ${ }^{1}$, Yemets I. M. ${ }^{1,2}$ \\ ${ }^{1}$ Ukrainian Children's Cardiac Center (Kyiv) \\ ${ }^{2}$ Shupyk National Medical Academy of Postgraduate Education (Kyiv)
}

The paper presents results of the operation of aortic valve replacement by the own pulmonary valve - the pulmonary autograft operation in patients with aortic valve disease and the modifications of the surgical technique.

Purpose: to analyze the twenty years of the pulmonary autograft procedure, to determine the causes of autograft dysfunction in follow-up period, to evaluate the effect of the autograft root reinforcement concept strengthening at two levels of the aortic root on the results of the operation.

Method and material. 200 consecutive patients of different age groups, which performed a pulmonary autograft operation for the period from 1996 to 2017. In 127 patients, our own surgical modifications (autograft root reinforcement) were used to strengthen the root of an autograft and to form a new pulmonary artery.

Results. Survival was $95.3 \%, 92.1 \%$ and $92.1 \%$ during 1,10 and 15 years of follow-up. The risk factors for mortality were: the age of patients under 1 year, the increase of the ischemic time and bypass, significantly reduced the risk with the use of surgical modifications.

Echocardiographic results: minimal neoaortic insufficiency was observed in 130 (76\%) moderate - in 25 patients (15\%), in $10(6 \%)$ patients - moderate-to-severe and severe - in $5(3 \%)$ patients. Risk factors for autograft dysfunction were: older age of patients, NYHA functional class, duration of operation; use of surgical modifications reduced this risk.

Conclusion. The use of a pulmonary valve as an aortic prosthesis provides growth of the neo-aortic root, a low incidence of aortic valve dysfunction, and a low frequency of reoperations. The use of own modifications of the operation showed effectiveness, greatly improving the immediate and long-term results.

Key words: pulmonary autograft, aortic valve disease, conduit, Ross operation.

\section{Двадцатилетний опыт операции легочного аутографта}

Романюк А. Н. ${ }^{1,2}$, Климишин Ю. И. ${ }^{1}$, Руденко Н. Н. ${ }^{1,2}$, Довгань А. М. ${ }^{1}$, Емец И. Н. ${ }^{1,2}$

${ }_{1}^{1}$ ГУ «Научно-практический медицинский центр детской кардиологии и кардиохирургии МОЗ Украины» (Киев)

${ }^{2}$ Национальная медицинская академия последипломного образования имени П. Л. Шупика (Киев)

В работе проанализированы результаты операции по замене аортального клапана собственным клапаном легочной артерии (операции легочного аутографта) у больных с аортальными пороками, представлены собственные модификации хирургической техники.

Цель работы - проанализировать двадцатилетний опыт операций легочного аутографта, определить причины дисфункции аутографта в отдаленном периоде, оценить влияние методики укрепления корня аорты на результаты операции.

Материалы исследования составили 200 последовательных пациентов разных возрастных групп, которым выполнена операция легочного аутографта за период с 1996 по 2017 гг. У 127 пациентов использовали собственные хирургические модификации по укреплению корня аутографта и формированию новой легочной артерии.

Результаты. За период наблюдения выживаемость составила 95,3\%, 92,1\% и 92,1\% через 1, 10 и 15 лет соответственно. Выявлены следующие фактории риска летальности: возраст пациентов до 1 года, увеличение времени пережатия аорты и искусственного кровообращения. Риск достоверно уменьшался при использовании собственных хирургических модификаций. Неоаортальная недостаточность наблюдалась: до 1-й степени (минимальная) - у 130 (76\%) пациентов, до 2-й степени (до небольшой) - у 25 (15\%), в 3-й степени (умеренно выраженная) - у 10 (6 $\%)$, выше 3-й степени (выраженная) - у 5 (3\%). Выявлены следующие предикторы увеличения риска дисфункции аутографта: возраст пациентов (его увеличение приводило к увеличению риска возникновения неоаортальной недостаточности $(\mathrm{p}=0,001)$ ), дооперационное клиническое состояние (ФК по NYHA), продолжительность операции $(\mathrm{p}=0,002)$. Применение модификаций укрепления корня неоаорты снижало риск возникновения неоаортальной недостаточности $(\mathrm{p}=0,002)$.

Выводы. Использование легочного клапана в качестве аортального протеза обеспечивает рост неоаортального корня, низкую частоту дисфункции аортального клапана и низкую частоту повторных операций на нем. Разработанные модификации операции показали свою эффективность, значительно улучшив непосредственные и отдаленные результаты.

Ключевые слова: легочный аутографт, порок аортального клапана, кондуит, операция Росса. 